\title{
THE EFFECT OF GENDER ON STOCK PRICE REACTION TO THE APPOINTMENT OF DIRECTORS: THE CASE OF THE FTSE 100
}

\section{BRENDA CARRON BRIAN LUCEY*}

JEL Codes: G14, G30, J16

Keywords : FTSE 100, Gender, Directors, Event Study

Abstract: We examine the effect of the appointment of directors on the share price of

FTSE companies. We find that the share price reaction to the appointment of Directors suggests that gender is not an issue in the appointment of Non-Executive Directors, but it does have an effect on the market reaction to the appointment of Executive Directors.

Corresponding Author: Brian M Lucey, School of Business and Institute for International Integration Studies, Trinity College Dublin, Dublin 2, Ireland \& Caledonian Business School, Glasgow Caledonian University, Cowcaddens Road, Glasgow, G4 0BA, Scotland, UK Email: Blucey@tcd.ie

Brenda Carron, School of Business, Trinity College Dublin, Dublin 2, Ireland , email carronb@tcd.ie 


\section{The Effect Of Gender On Stock Price Reaction To The Appointment Of Directors: The Case Of The FTSE100}

\section{Introduction}

Data on the percentage of female Directors suggests that the Boardroom is still a place where females are a rarity. Further analysis suggests that this is particularly so in relation to Executive Director and CEO positions, with female Non-Executive Directors being more commonly observed. (Sealy, Vinnicombe and Dolder (2009)). See Figure 1 below.

<figure 1 here>

Behavioural finance suggests that the psychological biases of market participants can manifest themselves in the behaviour of the market as a whole. Psychological research suggests that female candidates for male dominated roles tend to be assessed as less suitable for the position than their male counterparts. (Eagly and Karau (2002)). Were this true, we would expect to find that the appointment of female directors to the boards of major corporations would give a negative signal, resulting in a fall in share prices. Given that the role of Executive Director is more male dominated than the role of Non-Executive Director, one would expect that the stock price reaction to the appointment of new Executive Director would more clearly reflect the gender of the nominee, while the reaction to the appointment of a new Non-Executive Director may not. The purpose of this paper is to explore whether or not this is the case.

The primary basis for the investigation here is Lee and James (2007) who hypothesise that, given the general dislike of uncertainty, the added uncertainty of appointing a female CEO, due to the rarity of such appointments, should result in a more negative share price reaction as compared to the appointment of a male CEO. The authors found evidence to support this hypothesis, based on an analysis of 535 CEO appointments in the U.S between 1990 to 2000. Farrell and Hersch (2005) examine a sample of 111 female Board appointees to U.S. companies between 1990 and 2000, and find that 2 and 3 day CARs around the announcement dates are not statistically significant. However, by failing to provide any evidence on how the market reacts to male appointees, this tells us little about how the market views the fact that the Directors in question are female as opposed to male. If the market reacts favourably 
to the appointment of a male Director, but fails to respond to the appointment of a female, the market reaction to a female's appointment may still be characterised as negative, relatively speaking.

Campbell and Vera (2010) conducted an event study based on appointments to quoted Spanish firms between 1989 and 2001. Their sample was made up of over 4000 observations, only 100 of which related to female appointments. Looking at a 20 day event window, they found positive abnormal returns surrounding the appointment of female directors, which were found to be statistically negative using non-parametric tests. As in the case of Farrell and Hersch, one can criticise these results on the basis that the authors failed to analyse the male section of their sample. Looking at the Singapore stock exchange, Kang, Ding and Charoenwong (2010) take a sample of 53 announcements of female Director appointments made between 1994 and 2004. The authors find a positive average CAR over a two day event window on the appointment of a female Director of 1.22 percent. Based on regression results, they find that the market is least receptive towards the appointment of a female $\mathrm{CEO}$, more receptive to the appointment of a female Executive Director, and most receptive to the appointment of a female independent Non-Executive Director. The authors take this as indication that, due to gender stereotyping, female Non-Executive Directors are acceptable to the market, while female CEOs are not. Again, this conclusion may be criticised as, by failing to provide information on the market reaction to male appointments, the authors may be doing no more than telling us that the market reacts more negatively to CEO appointments than to Non-Executive Director appointments, regardless of gender.

\section{Data and Preliminary Analysis}

The starting point for the collection of the sample group of Director appointees was the constituents of the FTSE 100 as at 9 June 2010, with those companies which were not included in the index at any stage over the period January 2005 to June 2010 being excluded. ${ }^{1}$ The FTSE 100 was chosen on the basis that, given the size of the constituent companies, more comprehensive data should be obtainable for these firms. In addition, studies suggest that females tend to be appointed to larger firms,

\footnotetext{
${ }^{1}$ This resulted in us dropping 9 companies.
} 
(Carter, Simkins and Simpson (2003 )), hence using the FTSE 100 should increase the number of observations of female appointments.

This resulted in our database consisting of a sample of 491 director announcements in 91 companies. The data are summarized in Figure 2

$<$ figure 2 here $>$

The total percentage of female appointments in our sample (15.68\%) is higher than, but close to, the percentage of female Director appointments to FTSE 100 companies in 2009 as measured by Sealy, Vinnicombe and Dolder (2009) (14.7\%). Females make up a disproportionately high number of Non-Executive Directors, and hence of same day appointments, as multiple new Non-Executive Directors are likely to be appointed on the same day. As expected, females make up a disproportionately low number of CEO, CFO and Executive Director appointments

\section{Methodology and Results}

The methodology adopted is similar to that used by Lee and James (2007) who find that female CEOs are less well received that their male counterparts, but they fail to find evidence that gender affects the share price reaction to other top management appointees, like COOs or CFOs.

Three day cumulative abnormal returns (CARs) around the announcement date for all appointees were calculated using standard event study methodology Fama et al (1969) The expected return on security $s$ at time $t, E\left(R_{s t)}\right.$, is defined as that predicted by standard CAPM model:

$$
\mathrm{E}\left(\mathrm{R}_{\mathrm{st}}\right)=\mathrm{R}_{\mathrm{ft}}+\beta_{\mathrm{t}}\left(\mathrm{R}_{\mathrm{mt}}-\mathrm{R}_{\mathrm{ft}}\right)+\mathrm{e}_{\mathrm{st}}
$$

$R_{\mathrm{ft}}$, the risk free rate at time $t$, is defined by reference to the yield on a ten year UK Government Bond. $\beta_{t}$ is a rolling daily beta for each security, calculated on the basis of the excess return over the risk free rate on the security, and on the market return, during the preceding 6 months. $\mathrm{R}_{\mathrm{mt}}$ is the return on the market, defined as the FTSE 100 index, on day $t$. The abnormal return on a given security $s$ at a given time $t$ $\left(A R_{s t}\right)$ is given by the difference between the observed return on the security $\left(R_{s t}\right)$ and the expected return $\left(E\left(R_{s t}\right)\right)$.

$$
\mathrm{AR}_{\mathrm{st}}=\mathrm{R}_{\mathrm{st}}-\mathrm{E}\left(\mathrm{R}_{\mathrm{st}}\right)
$$


Following the approach taken by Farrell and Hersch (2005), CARs were calculated for a three day event window encompassing the date of the announcement, T, T-1 and $\mathrm{T}+1$. All data in relation to returns was obtained from Datastream.

The sample was then split into two sub-samples: Non-Executive Directors and Executive Directors and CEOs. Executive Directors and CEOs were retained as a single sub-sample as a result of the very low number of observations of female CEO appointments. ${ }^{2}$ These groups were further split into male and female sub-samples.

CARs were then assessed to see whether they were significantly different from zero. CARs for the entire sample, and for all male sub-groups were found to be statistically significant. Neither CARs for the female Non-Executive Director sub-sample, nor for the female Executive Director and CEO sub-sample, were found statistically significant. See Table 1 below.

\section{$<$ Table 1 here $>$}

The difference between CARs for the male and female Non-Executive Director subsamples was not found to be statistically significant. The difference between male and female Executive Director and CEO sub-samples was found statistically significant using a Welch F-test which accounts for the fact that the sub-samples may have differing variances. See Table 2 below.

\section{$<$ table 2 here $>$}

These results would tend to support the hypothesis that, while the market reacts more negatively to female Executive Directors and CEOs than to their male counterparts, gender is not an issue in relation to Non-Executive Director appointments.

As a robustness test, we also conducted regression analysis of the CAR's which allows for the introduction of control variables. Two regressions were calculated, one in relation to Non-Executive Directors, the other in relation to Executive Directors and CEOs. In both cases gender, the variable of interest, was represented by a dummy variable, being equal to one in the case of a female Director, and zero otherwise.

Following Lee and James (2007), a variable was included to indicate whether or not an appointee was an insider ${ }^{3}$. A dummy variable was included to capture any unusual

\footnotetext{
${ }^{2}$ There were only three such observations.

${ }^{3}$ This variable also largely captures the distinction between independent and non-independent Directors, although it does not capture those who, though not formerly employed by the company, are not classed as independent as a result of family ties or cross Directorships (see UK Corporate Governance Code (2010) Principle B.1.1). The inclusion of two variables, the
} 
reason for appointment, such as the death or sudden resignation of a former Director. A further dummy variable was also included to control for the fact that more than one Director appointment might be announced by the same company on the same day, which was set to one in the case of a same day appointment, and zero otherwise.

It was also decided to control for the possibility, in the case of Non-Executive Directors, that the appointee in question was also being nominated to the office of Chairperson and, in the case of Executive Directors, that the candidate was also being appointed CFO. Standardised market value, calculated by dividing the market capitalisation of a given company by the average market capitalisation of the index constituents, and standardised PE ratio, given by dividing the PE ratio of a given company by the average PE ratio of the index, was used to control for value versus growth effects ${ }^{4}$. Finally, dummy variables were included to capture industry effects.

The results of the regressions (see Tables 3 and 4 below) broadly support the results in relation to the significance of the difference between CARs.

$$
\begin{aligned}
& <\text { Table } 3 \text { here } \\
& <\text { Table } 4 \text { here }
\end{aligned}
$$

Gender was not found to be significant in relation to Non-Executive Directors, but was both negative and statistically significant in relation to Executive Directors and CEOs. In relation to the latter sub group, the gender variable produced a $-1.9 \%$ negative effect over the three day CAR window. Given that the variable designed to control for same day appointments was found to be significant in relation to the NonExecutive Director sample, and given that such multiple appointments may have been in relation to candidates of differing genders, or to different roles, all such overlapping observations were deleted, and the regressions were re-estimated. The results obtained were essentially similar to those produced prior to deletion and are available on request

\footnotetext{
first reflecting independence, the second reflecting insider status, was deemed undesirable as a result of the high degree of correlation between the two.

${ }^{4}$ Both the standardised market value and the standardised PE ratio for each observation were calculated using the market capitalisation and PE ratios of the particular company in question, and of the market, on the date of the announcement
} 
Appointment of a new chairperson was found to have a negative and statistically significant effect and, as expected, the coefficient on the variable controlling for the fact that an unusual reason was given for the appointment was negative.

The coefficients for standardised market value and standardised PE ratio were always negative as expected, with the variable reflecting size generally found to be statistically significant. The coefficients on the industry control variables were positive and significant in relation to two industry groups; Financials and Basic Materials, Oil and Gas. It might seem somewhat surprising that Financials carry a positive coefficient in light of the recent poor performance of financial stock. It may be that the market reacted especially positively to the appointment of a new Director to such companies, as incumbent Directors in that industry have come in for much criticism since the beginning of the financial crisis. Oil and gas stocks and, to a lesser extent, basic materials stocks generally outperformed the market between 2007 and 2010, which might explain the positive coefficient on that particular control variable.

It should also be noted that the adjusted R-squareds obtained were fairly low, being between 0.05 and 0.1 , indicating that the regressions lacked explanatory power. However, they were comparable to those produced by Lee and James (2007) of between 0.06 and 0.08 .

\section{Conclusion}

The obvious implication of the above results is that the stock market reacts against females appointed to the male dominated roles of Executive Director and CEO, but that the role of Non-Executive Director is regarded as suitable for either gender. In addition, a comparatively more negative share price response to female Executive Directors and CEOs provides a disincentive for a Board concerned with share price to appoint a female to these roles.

A number of caveats must be highlighted. First, the small number of observations of female appointments, especially in relation to female Executive Directors and CEOs, might cast some doubt as to the robustness of these findings. This is a problem frequently alluded to in the literature, and must be characterised as entirely unsurprising, given that the paucity of female Board appointees is generally the very motivation for research in this area. Hoping for a larger sample in future years is, in a 
sense, futile, as the existence of such an enlarged sample may well indicate the disappearance of the very biases that it is hoped to measure.

Second, the finding of a statistically significant difference between the appointment of male versus female Executive Directors and CEOs is open to the criticism that the sample was not split between CEOs and other Executive Directors. Such a division was felt to be impossible in light of the small number of observations in relation to female CEOs. It should be noted that Lee and James (2007), in addition to analysing CEO appointment data, also looked at top management appointees. Their finding that there was no significant differential price reaction to male versus female management appointees, but that there was a significant difference in reaction to male versus female CEOs, suggests that results based on a combined group of Executive Directors and CEOs might well be driven by the CEOs in the group. Even if that is the case, this does not impinge on the finding that there is no adverse response to the fact that a Non-Executive Director is female, which is an interesting result in itself.

It is submitted that further potential areas for research might involve trying to construct a larger sample of observations, in particular by looking at data over a larger number of years. Of course, the problem with such an approach is that the market's reaction to the gender of an appointee may well change over time. The issues involved with waiting for a higher number of females to be nominated to corporate Boards, hence producing a larger sample over a reasonably short time frame, have already been noted.

It might also be interesting to look at whether the market takes account of the idea of critical mass. In particular, one might explore the issue of whether the share price reaction to a female appointee becomes more negative as the number of females on the Board increases. If this is found to be the case, it could indicate that the market tends to regard a single female appointee as a mere token, with subsequent appointees being viewed as a threat to the established order. 
Figure 1 Percentage of female Directors on FTSE 100 Boards as per Female FTSE Report 2009
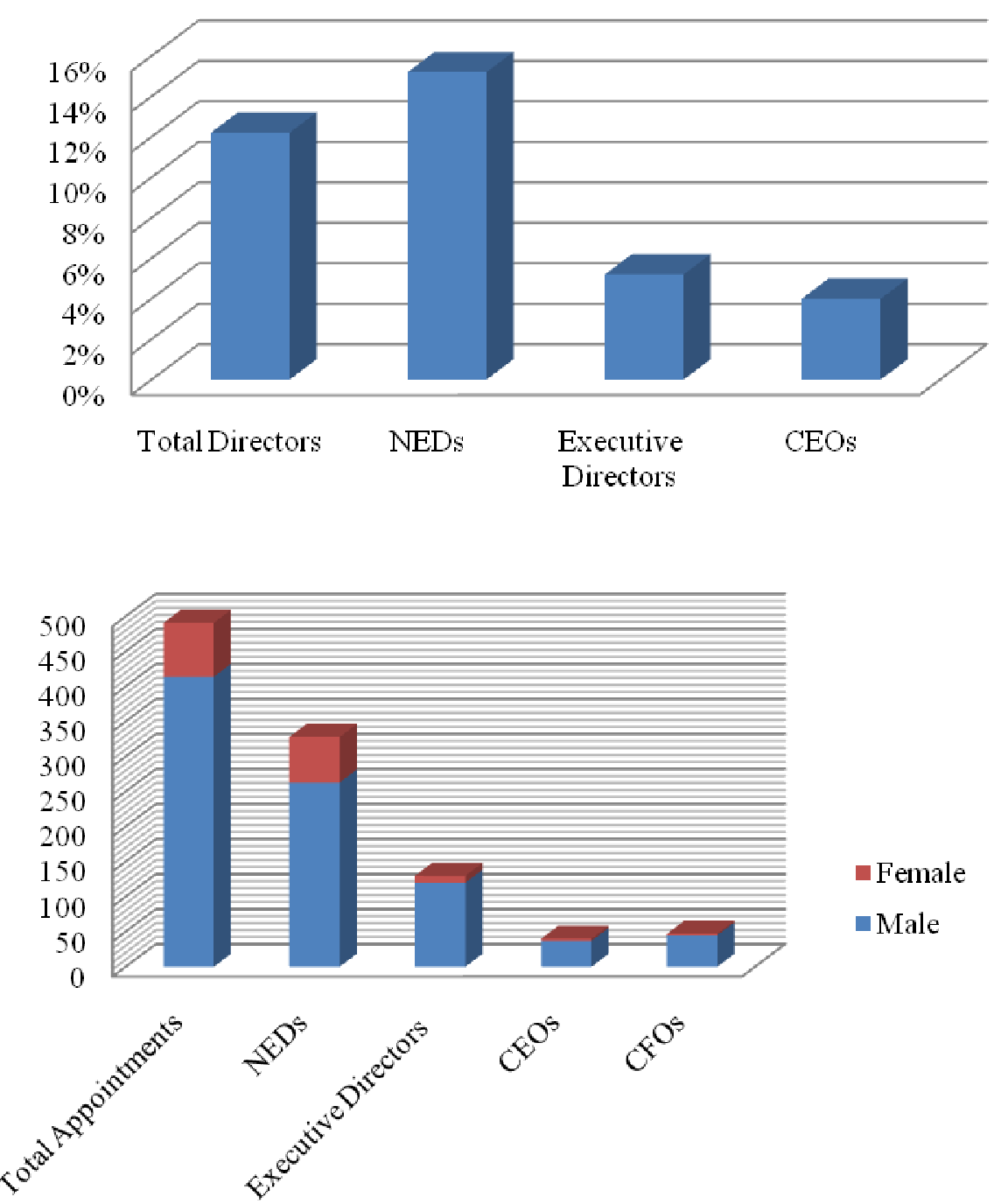
Table 1: Do Cumulative Abnormal Returns Differ across Roles?

\begin{tabular}{||l|c|c||}
\hline & NO. OF OBS. & MEAN \\
\hline Non Executive Directors & 327 & $0.005^{*}$ \\
\hline Male Non Executive Directors & 262 & $0.005^{*}$ \\
\hline Female Non Executive Directors & 65 & 0.002 \\
\hline Executive Directors and CEOs & 163 & $0.013^{* * *}$ \\
\hline Male Executive Directors and CEOs & 151 & $0.013^{* * *}$ \\
\hline Female Executive Directors and CEOs & 12 & -0.003 \\
\hline
\end{tabular}

Table analyses 3day Cumulative Abnormal Returns (CAR's) for Male and Female Non Executive Directors and between Male and Female Executive Directors and CEO's for the 91 FTSE companies : *** 1\% Significance, ** 5\% significance and $* 10 \%$ significance, all for tests of significance for CAR's to be different from zero.

Table 2: Do Cumulative Abnormal Returns Differ Across Gender and Roles?

\begin{tabular}{|c|c|c|c|c|}
\hline & MEAN & $\begin{array}{c}\text { NO OF } \\
\text { OBS. }\end{array}$ & $\overline{\text { VALUE }}$ & $\begin{array}{c}P \text { - } \\
\text { VALUE }\end{array}$ \\
\hline \multicolumn{5}{|c|}{ Executive Directors } \\
\hline Male & 0.014 & 151 & & \\
\hline Female & -0.003 & 12 & & \\
\hline All & 0.013 & 163 & & \\
\hline T-test & & & 1.235 & 0.268 \\
\hline Welch F-test & & & 8.220 & 0.006 \\
\hline \multicolumn{5}{|c|}{ Non Executive Directors } \\
\hline Male & 0.005 & 262 & & \\
\hline Female & 0.002 & 65 & & \\
\hline ALL & 0.004 & 327 & & \\
\hline T-test & & & 0.170 & 0.680 \\
\hline Welch F-test & & & 0.194 & 0.660 \\
\hline
\end{tabular}

Table analyses 3day Cumulative Abnormal Returns (CAR's) for Male and Female Non Executive Directors and between Male and Female Executive Directors and CEO's for the 91 FTSE companies : *** 1\% Significance, ** 5\% significance and $* 10 \%$ significance, all for tests of significance for tested pairs of CAR's to be different from zero. 
Table 3: Regression Analysis of Cumulative Abnormal Returns: Non Executive Directors

\begin{tabular}{||l|l||}
\hline INDEPENDENT VARIABLES & \multicolumn{1}{|c|}{ 3 DAY } \\
\hline & \\
\hline VAR
\end{tabular}

Table shows the results of a regression analysis of the determinants of 3day Cumulative Abnormal Returns (CAR's) 91 FTSE companies : *** $1 \%$ Significance, $* * 5 \%$ significance and $* 10 \%$ significance, all for tests of significance for tested pairs of CAR's to be different from zero. 
Table 4: Regression Analysis of Cumulative Abnormal Returns: Executive Directors and CEO's

\begin{tabular}{||l|l||}
\hline & 3 DAY CAR \\
\hline Variable & \\
\hline Constant & \\
\hline Gender & 0.019 \\
\hline Controls & $-0.019^{* *}$ \\
\hline Special reason for appointment & \\
\hline Firm Insider & $-0.019^{*}$ \\
\hline Same Day Appointment & 0.003 \\
\hline Also appointed CFO & -0.010 \\
\hline Financial & -0.002 \\
\hline Telecomms and Technology & $0.032^{* *}$ \\
\hline Utilities & $0.027^{*}$ \\
\hline Basic materials, oil and gas & -0.009 \\
\hline Consumer goods and services & $0.032^{* * *}$ \\
\hline Standardised Market Value & 0.004 \\
\hline Standardised PE ratio & $-0.005^{*}$ \\
\hline & -0.011 \\
\hline Significance of Regression & \\
\hline Adjusted R-squared & \\
\hline F-statistic & 0.055 \\
\hline Prob(F-statistic) & 1.793 \\
\hline \hline
\end{tabular}

Table shows the results of a regression analysis of the determinants of 3day Cumulative Abnormal Returns (CAR's) 91 FTSE companies : *** $1 \%$ Significance, $* * 5 \%$ significance and $* 10 \%$ significance, all for tests of significance for tested pairs of CAR's to be different from zero. 


\section{References}

Campbell, Kevin, and Antonio Minguez Vera, 2010, Female board appointments and firm valuation: Short and long-term effects, Journal of Management \& Governance 14, 37-59.

Carter, D. A., B. J. Simkins, and W. G. Simpson, 2003, Corporate governance, board diversity, and firm value, Financial Review 38, 33-53.

Eagly, Alice H., and Steven J. Karau, 2002, Role congruity theory of prejudice toward female leaders, Psychological Review 109, 573-598.

Fama, Eugene F., Lawrence Fisher, Michael C. Jensen, and Richard Roll, 1969, The adjustment of stock prices to new information, International Economic Review 10, 1.

Farrell, Kathleen A., and Philip L. Hersch, 2005, Additions to corporate boards: The effect of gender, Journal of Corporate Finance 11, 85-106.

Kang, Eugene, David K. Ding, and Charlie Charoenwong, 2010, Investor reaction to women directors, Journal of Business Research 63, 888-894.

Lee, Peggy M., and Erika Hayes James, 2007, She'-e-os: Gender effects and investor reactions to the announcements of top executive appointments, Strategic Management Journal 28, 227-241.

Sealy, Ruth, Susan Vinnicombe, and Elena Dolder, 2009, The female FTSE board report 2009, (Cranfield University School of Management). 